Nordic Concrete Research - Publ. No. NCR 62 - ISSUE 1 / 2020 - Article 2, pp. 21-39

\begin{tabular}{|l|r|}
\hline \multicolumn{1}{|c|}{ S sciendo } & \begin{tabular}{c} 
NCF $\begin{array}{l}\text { Nordic } \\
\text { Concrete } \\
\text { Federation }\end{array}$ \\
\hline $\begin{array}{l}\text { (C) Article authors. This is an open access article distributed under } \\
\text { the Creative Commons Attribution-NonCommercial-NoDerivs } \\
\text { licens. (http://creaticecommons.org/licenses/by.nc-nd/3.0/). }\end{array}$
\end{tabular} \\
\hline & $\begin{array}{r}\text { ISSN online 2545-2819 } \\
\text { ISSN print } \quad \text { 0800-6377 }\end{array}$ \\
DOI: $10.2478 /$ ncr-2020-0004 & $\begin{array}{r}\text { Received: March 26, } 2000 \\
\text { Revision received: June 3, 2020 }\end{array}$ \\
& Accepted: June 4, 2020 \\
\hline
\end{tabular}

\title{
Making Concrete Pavements Competitive by Using the Standardized Framework for Comparisons of Infrastructure Projects in Terms of Cost- Efficiency and Climate Impact
}

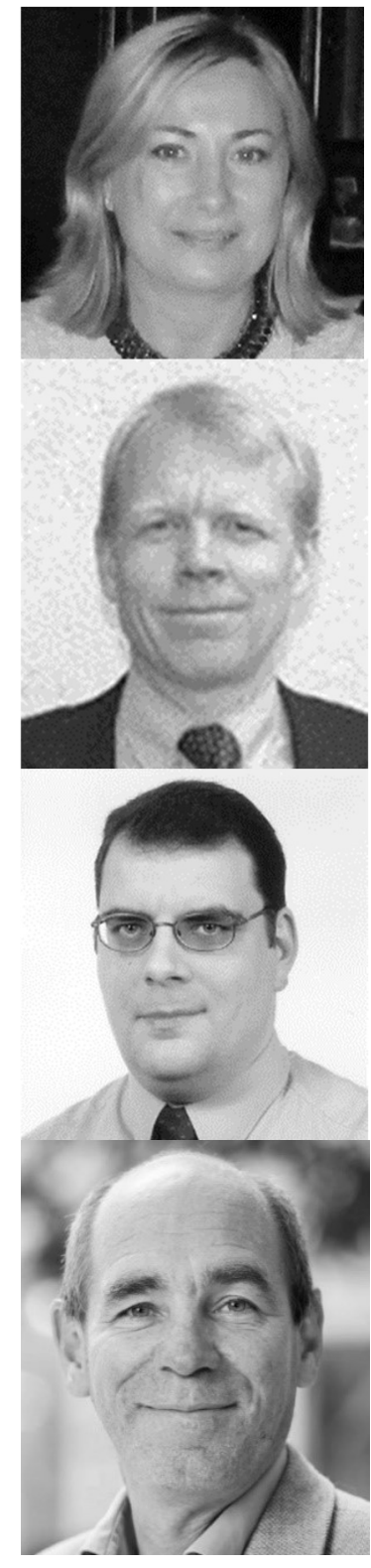

Larissa Strömberg

Ph.D., Affiliated faculty

KTH Royal Institute of Technology

Division of Concrete Structures

SE-100 44 STOCKHOLM, Sweden

e-mail: larissa.stromberg@byv.kth.se

Johan Silfwerbrand

Ph.D., Professor

KTH Royal Institute of Technology

Division of Concrete Structures

SE-100 44 STOCKHOLM, Sweden

e-mail: johan.silfwerbrand@byv.kth.se

Anders Ansell

Ph.D., Professor

KTH Royal Institute of Technology

Division of Concrete Structures

SE-100 44 STOCKHOLM, Sweden

e-mail: anders.ansell@byv.kth.se

\section{Staffan Hintze}

Ph.D., Adj. Professor

KTH Royal Institute of Technology

SE-100 44 STOCKHOLM, Sweden

e-mail: staffan.hintze@ncc.se 


\begin{abstract}
Despite the new Swedish client requirement to reduce the climate impact from the construction of roads, there has been relatively little research so far on how the optimization measures regarding the environmental impact of road pavements can be integrated in the traditional design. An increase in axle weights, changes of the traditional ways of travel, e.g. the use of automated and guided vehicles, and stricter customer requirements on reducing the climate impact require new approaches to steer the road and pavement industry towards more climate neutral solutions. This paper analyzes the latest standards for sustainability assessment of engineering works in an attempt to adjust these standards for assessing various road design options in a comparable and fair way, also when various materials are included.
\end{abstract}

Key words: Structural Design, Sustainability, Mix Design, Modelling.

1.

\title{
INTRODUCTION
}

\section{1 \\ General}

In the next few years substantial Swedish investments will be made in mega road projects, such as the West Link in Gothenburg and the Bypass Stockholm. There is a great interest among Swedish public clients such as the Swedish Transport Administration (STA) [1] and municipalities [2] in using new innovative solutions and material choices in these projects in order to build more climate neutral roads. To maintain the competitiveness of sustainable construction in the Swedish construction industry, these ambitions must be broken down from the policymaking level to tangible guidance at the level of construction and civil engineering projects. This can then make a difference and all the actors at all stages can contribute in a meaningful way. Some Swedish contractors and material suppliers have already started to perform the climate optimization of their products and solutions as well as optimization of supply chain often as a part of an internal strategical work with cost reduction. An innovative climate-efficient pavement is often created long before the actual bidding process. If a particular vendor claims that he or she can build sustainable and "green" roads, this has to be measured and verified by a standard method. For the moment, there is a lack of ability to present information to enable project stakeholders to understand the inter-relationship between costs (over the whole life), time and design quality and also take account of a wider environmental impact (notably energy performance and $\mathrm{CO}_{2}$ emissions) of the road pavements. Comparison of alternative materials and construction structures based on technical and functional characteristics as well as sustainability performance aspects, such as environmental and economic, in the whole life-cycle perspective will become a vital ability for the construction industry in order to fulfil the climate reduction worldwide goals.

1.2

Scope

The purpose of the paper is to increase the understanding of the challenges associated with adapting the current road design method to the LCA and LCCA methodology. The focus is to support the design and construction of sustainable roads based on the latest standards for sustainability assessment of engineering works in terms of cost-efficiency and climate impact. 


\subsection{Concrete roads in Sweden}

The total length of the concrete road network in Sweden is approximately. $67 \mathrm{~km}$, see Table 1 . The proportion of the concrete roads is less than 1 percent of the total Swedish road network.

Table 1 - Concrete Roads in Sweden.

\begin{tabular}{lccc}
\hline Section of road & Year & Length $(\mathrm{km})$ & Status \\
\hline E6 Vellinge & 1972 & 13 & Overlaid with asphalt \\
E4 Helsingborg & 1978 & 7 & Overlaid with asphalt \\
E4.65 Arlanda & 1990 & 1,6 & In use \\
E6/120 Falkenberg 1 & 1993 & 15 & In use \\
E6/120 Falkenberg 2 & 1996 & 13 & In use \\
E20 Eskilstuna & 1999 & 14 & In use \\
E4 Uppsala & 2006 & 23 & In use \\
\hline Total & & 87 & \\
\hline In use & & 67 & \\
\hline
\end{tabular}

Silfwerbrand [3 \& 4] has identified several reasons. The lack of experience in design, construction, and repair of concrete roads is the major challenge, along with several others, such as:

- The asphalt pavements are considered a cheaper alternative, taking into account the initial investments, but their maintenance might be costly over time. The current procurement system after an estimated investment cost limits the use of materials and/or designs with longer service life and less maintenance.

- Sweden is a relatively sparsely populated country, which means that most roads have too low traffic volumes for investment in more expensive concrete roads.

- There is a very strong tradition to build asphalt roads.

- There is a lack in national experience in design, construction, and repair of concrete pavements. Often, the skills of both clients and contractors are lacking. All Swedish concrete roads have been paved by using German or Dutch slip form pavers. The road project size has an essential impact to make a concrete pavement a more profitable option than an asphalt pavement.

- Most procurement and management of infrastructure in Sweden is done by the STA, whose structural organization has separate divisions and "wallets" responsible for new production and repair \& maintenance contracts.

- Current problems with premature wearing of the current concrete roads, e.g. the Eskilstuna and Uppsala road (E18) were caused by an incorrect choice of coarse and fine aggregates for the wearing concrete layer [5].

The last reason above can in turn be explained by a successive decreased quality in Swedish concrete pavements since the completion of the Arlanda road in 1990. The concrete compressive strength has successively been lowered from above 120 to $60-70 \mathrm{MPa}$ in the two latest road sections (Figure 1, on the left). The Swedish practice in concrete pavement construction is a twolayer concrete pavement cast wet-to-wet. The 70-80 $\mathrm{mm}$ thick top layer is produced by a wearresistant concrete mix combining high strength concrete with selected (expensive) aggregate particles with high wear-resistance. The $130-150 \mathrm{~mm}$ thick bottom layer is produced with a concrete mix of similar strength but with local (less expensive) aggregates. Dolk [5] has investigated the concrete mixes for the five concrete pavements constructed after 1990 and the conclusion is that in the youngest concrete pavement (E4 Uppsala), the wear-resistant aggregate 
was mixed with a local aggregate resulting in a not sufficiently strong top layer concrete mix (Figure 1, on the right). This leads to premature rutting.
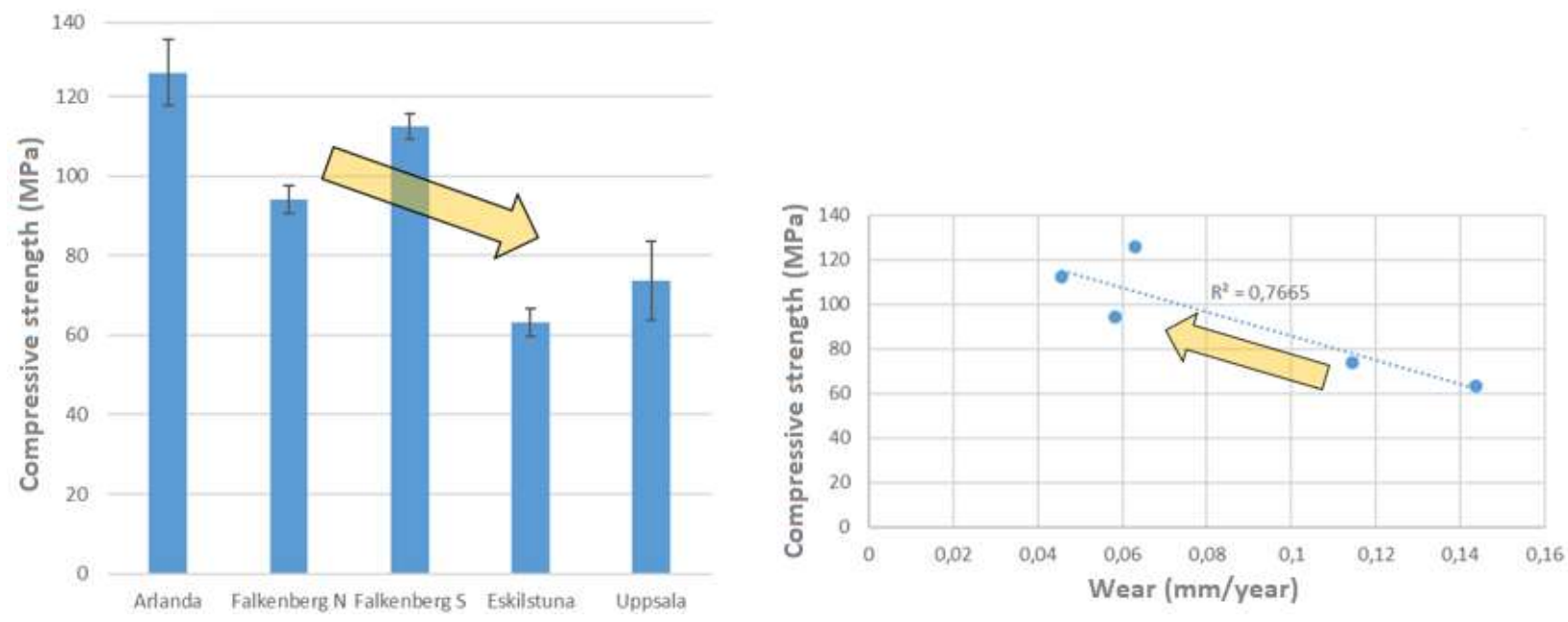

Figure 1 - Due to short-time economic savings, the concrete compressive strength was successively lowered in more recent Swedish concrete pavements (top) resulting in an unfavourable successive increase in rutting [5].

\subsection{Current practice with LCA, LCCA and technical design in road projects}

The European countries and the US have well-established methodologies and software tools for pavement design. These countries have used Life Cycle Assessments (LCA) and Life Cycle Cost Assessment (LCCA) on several infrastructure projects, but the procedure is not standardized and not completely integrated with pavement design. Despite the new client requirement to reduce the climate impact, there has been relatively little research so far on how the optimization measures in order to reduce the environmental impact of road projects can be integrated in the traditional design.

There are some contractors and material suppliers who already conduct LCAs in order to improve the road pavement's climate performance. The STA has developed and implemented an Excelbased calculation tool for the LCC for road structures, the ambition being to conduct LCCA for the evaluation of all road projects. A previous study has shown [6] that claiming an LCCA is not widespread among Swedish public clients, although both the EU directive 2014/24/EU [7] and the Public Procurement Act [8] recommend applying life-cycle costs for the evaluation of tender proposals instead of the traditional procurement based on price.

The LCAs and LCCAs can be conducted in many ways and if using different system boundaries, different assessment methods, and the way to model the entire life cycle the results will be incomparable [9]. At present, LCAs and LCCAs are not standardized and are performed in different ways, using different commercial software with different methods. The current lack of a comparable, reliable industry wide-used standard is anticipated to become an important barrier to improve the actual climate performance of infrastructural projects. In Sweden, separate design methods and tools are used to analyze and optimize different performance aspects of pavements [10], see Table 2. 
Nordic Concrete Research - Publ. No. NCR 62 - ISSUE 1 / 2020 - Article 2, pp. 21-39

Table 2 -Current used tools for optimizing various performance aspects of road pavements [10].

\begin{tabular}{|c|c|c|c|c|}
\hline Owner & Tools & Purpose and optimization area & System bounderies & EPD modules \\
\hline \multicolumn{5}{|c|}{ Technical design tools } \\
\hline STA & PMS Objekt [12] & $\begin{array}{l}\text { Technical design and optimization } \\
\text { of asphalt road structures. }\end{array}$ & $\begin{array}{l}\text { The whole road } \\
\text { structure } \\
\text { (superstructure+ } \\
\text { substructure) }\end{array}$ & Partial A-B \\
\hline STA & PMSV3 [13] & $\begin{array}{l}\text { Gathering } \\
\text { statistical/empirical/modelling } \\
\text { data on pavements' service lives. }\end{array}$ & Non-standadized & Partial C \\
\hline \multicolumn{5}{|l|}{ LCCA tools } \\
\hline STA & $\begin{array}{l}\text { LCC tool for road } \\
\text { superstructure } \\
{[14]}\end{array}$ & $\begin{array}{l}\text { LCC for roads, optimization of } \\
\text { initial and maintenance costs. }\end{array}$ & Only superstructure & Partial A-C \\
\hline \multicolumn{5}{|l|}{ LCA tools } \\
\hline STA & EKA tool $[15]$ & $\begin{array}{l}\text { LCA for asphalt pavements, } \\
\text { optimization of the climate impact }\end{array}$ & Only superstructure & $\begin{array}{l}\text { Partial A1- } \\
\text { A3 }\end{array}$ \\
\hline STA & $\begin{array}{l}\text { "Klimatkalkyl" } \\
\text { tool [1] }\end{array}$ & $\begin{array}{l}\text { LCA for infrastructure projects, } \\
\text { reporting/optimization of the } \\
\text { climate impact. }\end{array}$ & $\begin{array}{l}\text { The whole road } \\
\text { structure }\end{array}$ & $\begin{array}{l}\text { Partial A1- } \\
\text { A3 }\end{array}$ \\
\hline $\begin{array}{l}\text { European } \\
\text { (CEN) and } \\
\text { international } \\
\text { (ISO) } \\
\text { standards } \\
\text { organizations }\end{array}$ & EPD $[20,21]$ & $\begin{array}{l}\text { EPD for asphalt, EPD for } \\
\text { concrete, EPD for road etc. Only } \\
\text { reporting. }\end{array}$ & $\begin{array}{l}\text { One asphalt or } \\
\text { concrete layer or the } \\
\text { whole road structure }\end{array}$ & $\begin{array}{l}\text { A-D } \\
\text { (Compulsory } \\
\text { A1-A3) }\end{array}$ \\
\hline
\end{tabular}

The technical design of road pavements complies with the STA regulations [11] and is carried out using the software PMS Objekt [12]. The STA uses an internal database with information on road monitoring, PMSV3 [13]. Life Cycle Cost Assessment (LCCA) for repairs of existing or planning of new road projects are done using the STA's LCCA tool for road superstructures [14]. The Swedish industry uses EPDs as a declaration of both asphalt and concrete pavements' environmental performance. The STA places bidding requirements on estimation of the environmental impact of asphalt pavements with the LCA tool for asphalt pavement, EKA [15]. STA has also the requirement to calculate and report the climate impact, e.g. from a road in the "Klimatkalkyl" tool [1]. Limitations for current LCA and LCCA analyses also differ between the studies, which means that the calculation results from those tools are not comparable. There is currently no accepted theory for setting requirements and verifying the performance of road designs based on a multidisciplinary overall performance, which includes technical, climate and cost efficiency. This is especially relevant with increasing needs in the development of new infrastructure and the increasingly stricter Swedish strategic goals of reducing the climate impact.

2. METHODOLOGY AND STANDARDIZATION

\subsection{Fair comparison brings lower prices and higher climate-efficiency}

In the European Union and not least in Sweden, there is a strong political drive to develop standards and regulations to reduce the climate impact of the transportation industry. The effect of these standards on reducing the climate impact for pavements in the whole life-cycle perspective is unknown and has not been verified with laboratory or field tests. Assessment of the measures that give the most cost-effective emission reductions is one of the more difficult tasks in transitioning the pavement industry to become more climate neutral and its complexity has been 
illustrated by McKinsey [16 \& 17], with a global cost curve that shows opportunities and costs of various measures for reducing greenhouse gas emissions. The conclusion is that the world is changing, and the measures we consider expensive today can become relevant in the future through adaptations, innovations, and technological development. Figure 2 has been developed by the International Energy Agency [18] and is based on McKinsey's curve for opportunities and costs for reducing greenhouse gases to show where various instruments have the highest costeffectiveness.

In a perfect world, pricing of carbon dioxide emission would have been enough to transform the industrial processes so that the most cost-effective climate measures are implemented first. In reality, market failures mean that pricing should be accompanied by complementary tools. To the left of the diagram in Figure 2 there are climate measures that have a "negative price" - that is, they are theoretically profitable to implement. For this reason, research, development, and demonstration are also important components of the policy mix [18]. There are various opportunities for investment in the various business sectors, which to some extent can explain why good ideas and cost-effective solutions do not always reach actual measures.

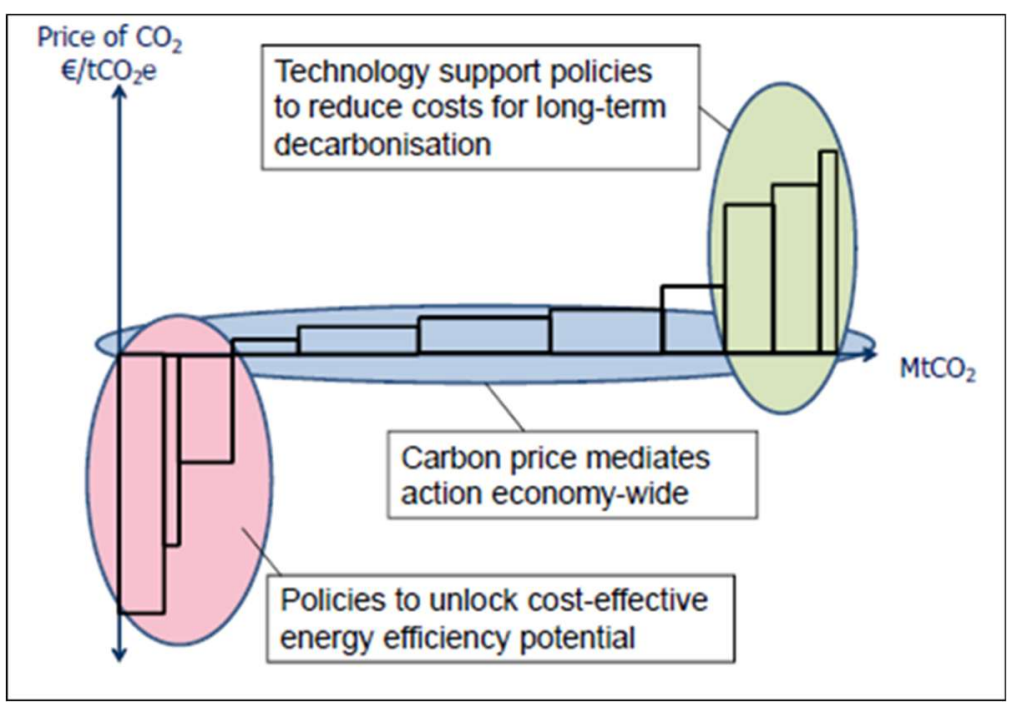

Figure 2 - Cost-effective use of political and market-driven instruments for reducing greenhouse gases [18].

The need for a theoretical framework for correctly conducted comparisons of various pavement materials in terms of various sustainability aspects such as functionality, environmental performance and cost-efficiency is increasing. This is especially the case for new types of climateneutral fuels, machines, and materials, so that sub-optimizations and oblique competition do not arise at various stages of the construction process, i.e. in early planning, procurement, detail planning, production, operation, maintenance and recycling.

A recent research report from Massachusetts Institute of Technology (MIT) [19] has shown that increasing inter-industry competition lowers paving unit prices for both asphalt and concrete, which is likely to result in significant savings for both clients and taxpayers. A wider choice of pavement materials would result in a fairer competition with lower prices and higher climateefficiency. 


\subsection{Comparison on material level}

The construction industry in Europe and USA have come a long way in terms of implementation of the Environmental Product Declarations (EPDs) as a standardized measure of the environmental performance. The information in an EPD can also be accepted for use in reporting, marketing, procurement, and development of the product. The EN 15804 standard [20] specifies an industry-approved method for the development of an EPD for a construction product. There is the international standard, ISO 21930 [21] used in the US as an alternative to the European standard EN 15804. Both standards describe the calculation method for estimating environmental impact of construction materials, see Figure 3. According to these standards, there is a minimum requirement for an LCA to include the environmental impact from raw material extraction up to the factory gate ("cradle-to-gate"), which is referred to in the standards as module A1 to A3. The EPDs are currently limited to the assessment of environmental impact of the pavement manufacturing (module A1 to A3). Therefore, the current implementation of the EPD system is limited to comparison of the same type of the pavements, e.g. the same asphalt mix from different producers [22].

A more comprehensive EPD that includes other EPD modules such as the service stage (module $\mathrm{B}$ ) and the end-of-life stage (module $\mathrm{C}$ ) requires more specific data on the future maintenance and repair scenarios [22]. The lack of this data today prevents the wider use of EPDs as a certificate of environmental performance in infrastructure projects in Sweden [23]. The future scenarios on the transport options between the production plant and construction site (module A4), paving technology (module A5), operation and maintenance scenarios (module B), demolition and recycling of pavement (module $\mathrm{C}$ ), and reuse of the recycled pavement in new projects (module D) must be specified.

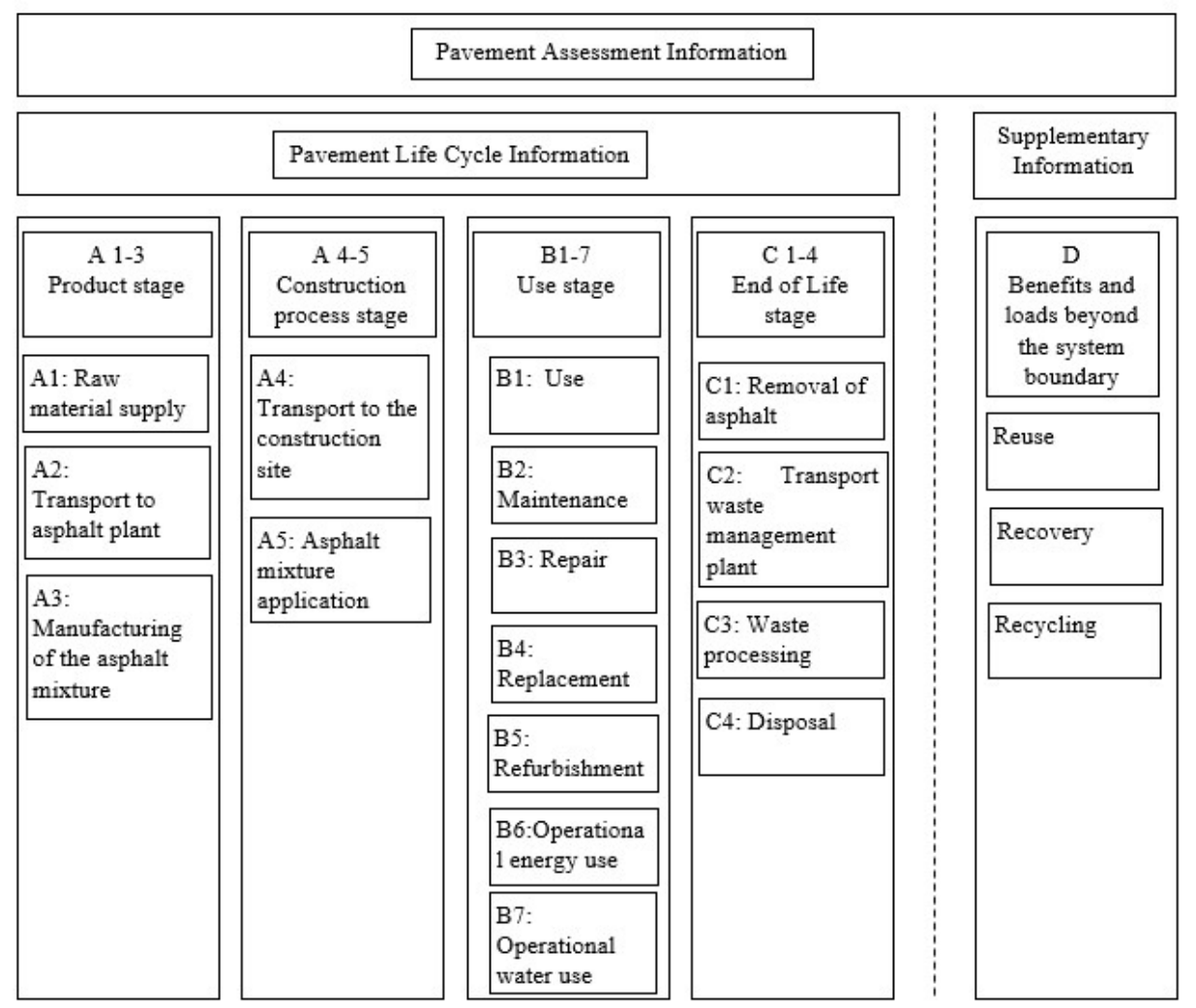

Figure 3 - The environmental impact of a pavement divided into several life cycle stages or modules, from EN 15804 [20] and ISO 21930 [21]. 
It is expected that the European standard being developed by CEN / TC 227 / WG6 will define the reference scenarios for modules A4-D as a common ground for further comparability for all life cycle stages of asphalt pavements [24]. Currently, in Europe there is no similar standardization project for developing reference scenarios for concrete pavements. In the new version of the European EPD standard, EN 15804, which will be implemented around all countries in the European Unit as of September 2020, reporting on the environmental impact of module A1-A3, C1-C4 and D will be mandatory.

\subsection{Comparison on engineering works level}

Within the international standardization community, active work is underway with the development of a theoretical framework for assessment of various sustainability aspects of engineering works as bridges, tunnels, roads etc. The goal of the ongoing standardization is developing methods for assessing various design options (including various material types) in a comparable and fair way. The EN 15643-5 [25] has created common system boundaries for methods for assessing sustainability aspects of civil engineering projects and related environmental, social, and economic performances, as well as technical and functional performances, to each other, see Figure 4.

According to the EN 15643-5, sustainability performance assessments must be made for design alternatives with the same functional equivalence and within the same system boundaries, which creates comparability between different material choices.

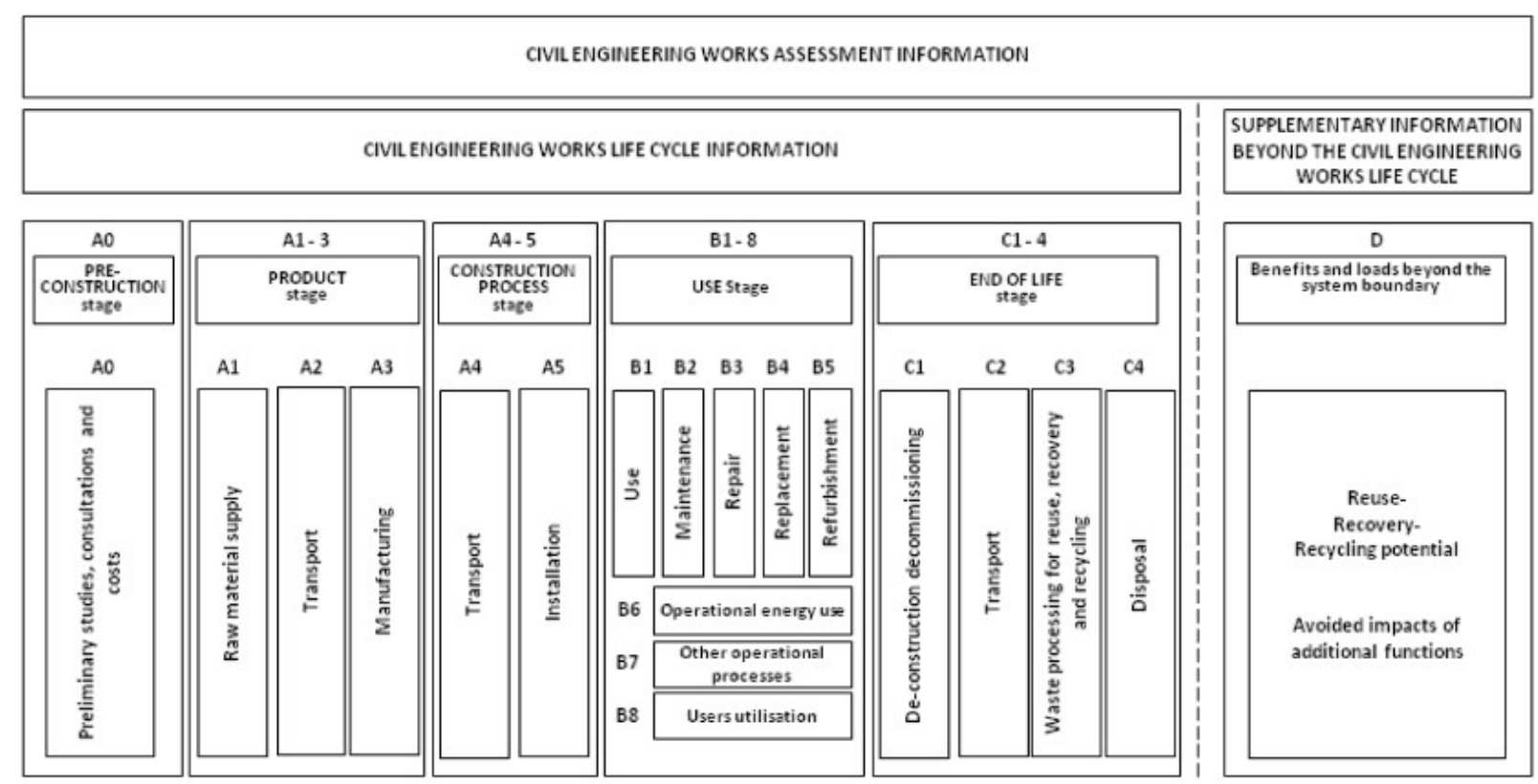

Figure 4 - Information modules applied in the assessment of environmental, social and economic performance of a civil engineering works according to EN 15643-5 [25].

When choosing a functional equivalent, the standard refers to the national requirements and guidelines for specific construction types, such as roads, bridges and tunnels. For the assessment of the sustainability performance of civil engineering projects the life cycle starts with the preparatory works and administrative processes, see Figure 4. It proceeds through the contractual arrangements for design and specification, acquisition of raw materials, manufacturing and 
procurement of products, construction work processes, handover for use, commissioning, (module A0 to A5) actual use including maintenance, repair, replacement, refurbishment and operation of the civil engineering works (module B1 to B7) and finally at the end of life, decommissioning, deconstruction or demolition, waste processing in preparation for reuse, recycling and energy recovery and other recovery operations, and disposal of waste (module $\mathrm{C} 1$ to $\mathrm{C} 4$ ). The potential for re-use, recovery and recycling of materials and/or energy recovery beyond the system boundary should also be assessed and, where relevant, reported as supplementary information in module D. This requires the development and use of appropriate scenarios describing the assumptions (or, where known, real information) that can be applied to models for construction, use, and end-of-life stages (modules A4 to D) in Figure 4.

A recently published draft of EN 17472 [26] provides some specific methods and requirements for the assessment of environmental, economic and social performances of civil engineering works while taking into account their functionality and technical characteristics. Figure 5 shows how the functional equivalence, and the technical and functional characteristics that differ from those required, either by the client's brief or through regulations, are to be declared and communicated with the results of the assessment.

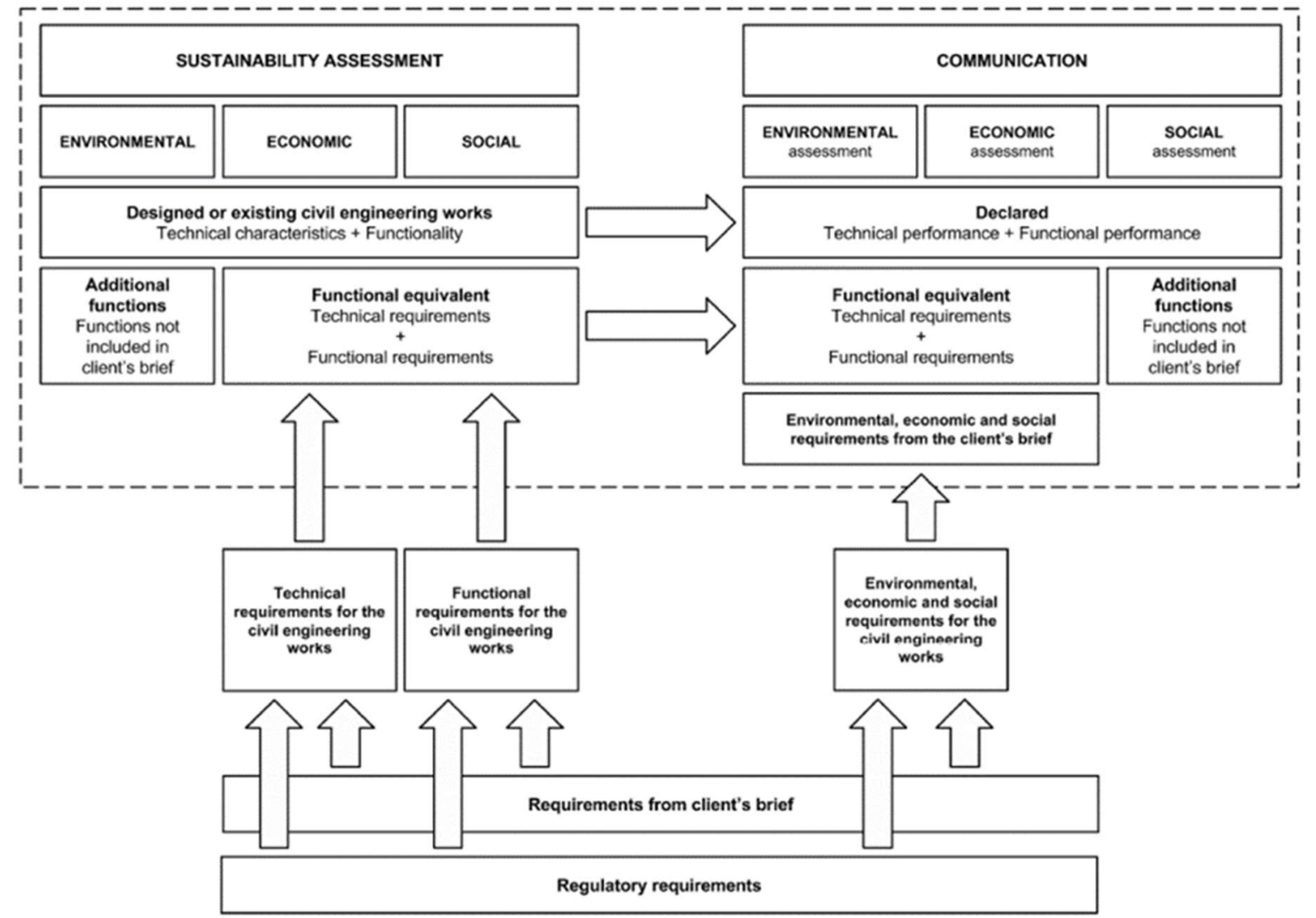

Figure 5 - Concept of sustainability assessment of civil engineering works according to prEN $17472[26]$.

Both EN 15643-5 and prEN 17472 are applicable to new and existing civil engineering projects and refurbishment projects. The assessment of environmental and economic performances of civil engineering works is recommended to be based on LCA and LCCA. The approach to the assessment covers all stages of the civil engineering works life cycle and includes all related construction products, processes and services, used over the life cycle. The environmental performance can be based on data obtained from Environmental Product Declarations (EPD) and 
additional indicators. The assessment of social performance differs from the assessment of economic and environmental aspects because it requires both quantitative and descriptive approaches [26].

Functional equivalence is described as quantified functional requirements and/or technical requirements for roads or a part of roads for use as a basis for comparison. The functional equivalence must reflect the entire road's life cycle and should be used to define the relevant comparable service life scenarios for a certain road project. Service life scenarios may be based on the client's project brief, national guidelines, and EPD-system's rules for the infrastructure projects. Subsequently, alternative materials for a road pavement can be compared based on this project-specific equivalent. In all cases the principle that the basis for comparison of the assessment is the entire road, shall be maintained by ensuring that [26]:

- the same functional requirements as defined by legislation or in the client's brief are met,

- the environmental, social, economic and technical performance of any assembled systems, components, or products excluded, if any, are the same,

- the amounts of any material excluded, if any, are the same,

- excluded processes, modules or life cycle stages, if any, are the same,

- the influence of the systems compared, on the entire road aspects and impacts, are taken into account.

The client's brief and regulations can provide information on most of these items. Functions not required in the client's brief are considered additional functions. Once the client decides to include those additional functions in the brief, they are not additional functions anymore, and shall be included in the functional equivalence. Where this is not the case, the assessment shall include the assumptions that are made, the scenarios and the sources of information used by the assessor. Where no required service life is specified by the client or by regulation, the design life length may be used. If the design life is used (which can be longer than the required service life), how it is derived shall be described, e.g. determined on the basis of empirical, probabilistic or statistical data.

\section{3.}

\section{FRAMEWORK FOR COMPARISONS BETWEEN ROAD PAVEMENTS IN TERMS OF COST-EFFICIENCY AND CLIMATE IMPACT}

This project has analysed the above-mentioned standards and has identified the most essential inputs required to conduct the assessment and comparison of alternative pavement materials within a road project. An attempt to implement these theoretical findings on concrete pavement applications was made. The above-mentioned standards have created a general framework for the sustainability assessment and may be used for various types of engineering works, such as bridges, roads, tunnels etc. In this study, the above-mentioned standards were applied for assessment of sustainability of road pavements in infrastructure projects. The standards have established a general standardized framework for sustainability assessment of engineering works at different levels, from assessment of inbuilt materials, building parts and, finally, the entire engineering construction such as e.g. a road. 


\section{1}

\section{Application of the standards with respect to comparison of road pavements}

The assessment at the highest level, i.e. the road level, is an accumulated assessment, where the environmental impacts of individual materials and building parts are summarized in order to assess the environmental impact of the entire road project. There is a fundamental distinction between methods for assessment of the sustainability aspects of building materials and the whole road, according to these analysed standards. The sustainability assessment of civil engineering works uses different types of information than assessment of materials, according to the reviewed standards [26]. In this study, the mapping of different levels of sustainability assessment of road projects in the current standards was performed, see Figure 6.

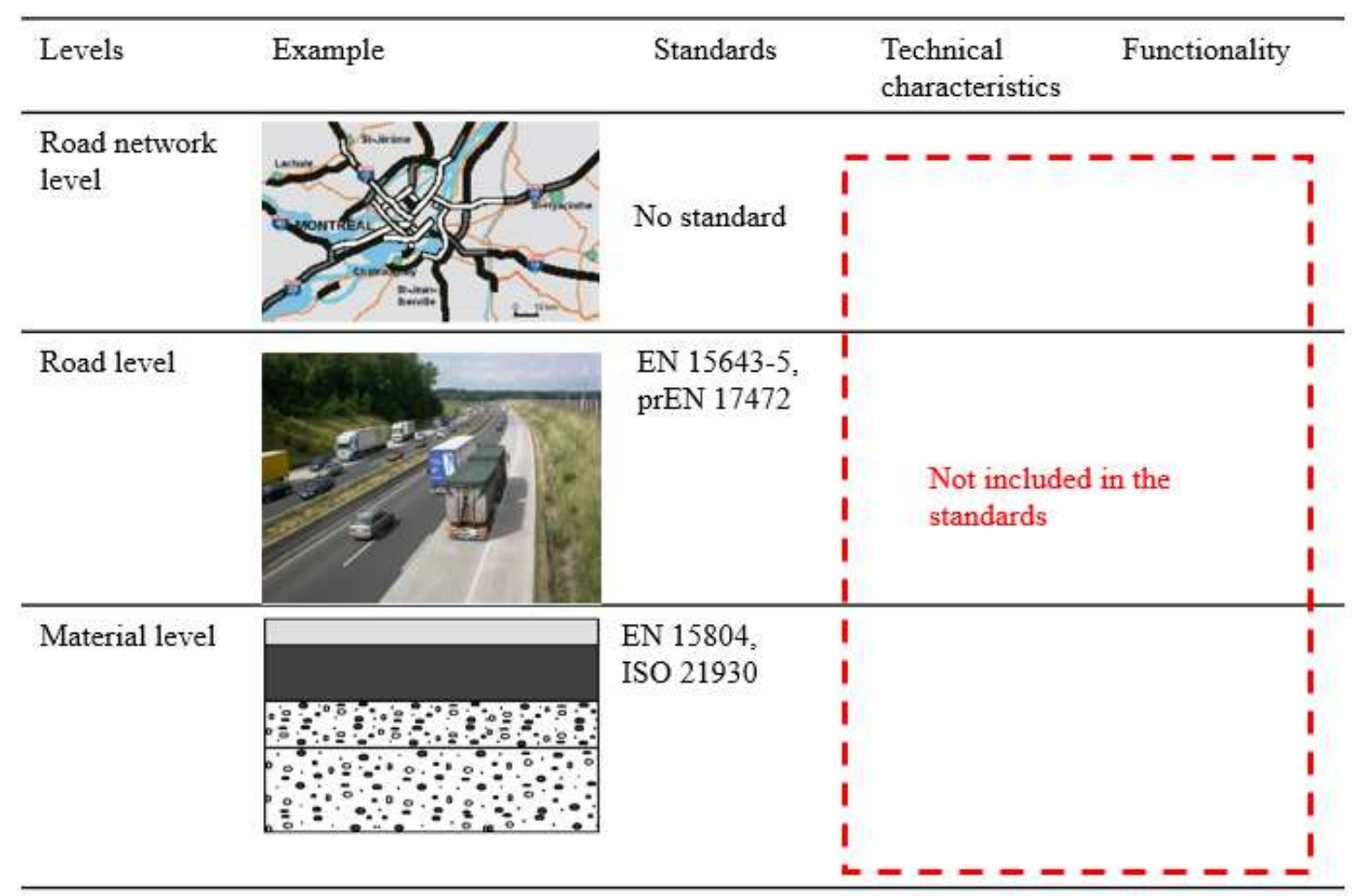

Figure 6-Mapping of different levels of assessment of sustainability of construction work in the current standards has been done in this study.

There is no standard for sustainability assessment at the road network level, which is too general to handle within the system analysis methods as an LCA is. The results of the sustainability assessment at the road level may provide information on the different types of indicators, the related service life scenarios, and the life cycle stages included in the assessment. According to EN 15643-5, the EPDs for individual materials can only be used to compare the environmental impacts between different asphalt mixes or between asphalt and concrete pavements if the system boundaries for the EPDs include all life cycle stages of the entire road structure and all crosssections of the road. According to EN 15643-5, when comparing results for objects at levels lower than the entire road, it is assumed that objects are comparable with regards to function, performance and other characteristics that are required in order for the objects to be used in the same place in the road structure. In carrying out assessments, scenarios and a functional equivalence are determined at the road level, which means that the descriptive model of the road with the major technical and functional requirements can be retrieved from the client's brief or in the national technical regulations. The evaluation of technical and functional performance is 
beyond the scope of EN 15643-5 and prEN 17472 that leaves some potential interpretation challenges when applying these standards for the evaluation of a road project.

The application of sustainability assessment at the road level, i.e. at the engineering works level, has previously been done for a few actual road projects, but not according to the EN 15643-5 or prEN 17472. The most used standard for the road projects is EN 15804 which describes the environmental assessment at the materials and products level. The STA guidance on the climate assessment of infrastructure projects [26] refers to the EN 15804 that defines calculation rules for EPD for building materials. The guidance does not refer to the EN 15643-5 in any matter, although this standard is especially developed for the sustainability assessment of more complex engineering systems as roads are.

According to EN 15643-5, the result of any environmental assessment should be presented as impact of a material or a road per a reference (or functional) unit. A common reference unit can be derived from the functional equivalence and be used to present the result of the indicators of the environmental and economic assessments relative to the functional equivalence. A reference unit can be dimensionless or qualified with a dimension (e.g. per vehicle, per $\mathrm{m} 3$ of water etc). This study has identified several options for reference or functional units for roads or road pavement materials currently used for the LCAs, see Table 3. 
Table 3 - Most used functional units for presentation of sustainability assessment of roads, concrete pavement, and asphalt pavement.

\begin{tabular}{|c|c|c|}
\hline Standard & Application area & Recommendation on the comparison unit \\
\hline \multicolumn{3}{|l|}{ Material level } \\
\hline EN 15804 [20] and & All construction products & - $\quad$ Mass $(\mathrm{kg})$, e.g. $1 \mathrm{~kg}$ of cement \\
\hline PCR for construction & & - $\quad$ Length (m), e.g. 1 metre of pavement \\
\hline products [27] & & - $\quad$ Area $\left(\mathrm{m}^{2}\right)$, e.g. 1 square metre of asphalt pavement \\
\hline & & - $\quad$ Volume $\left(\mathrm{m}^{3}\right)$, e.g. 1 cubic metre of concrete \\
\hline & & - $\quad$ A different unit may be declared for reasons that. \\
\hline $\begin{array}{l}\text { PCR for concrete and } \\
\text { concrete elements [28] }\end{array}$ & $\begin{array}{l}\text { Concrete pavements, } \\
\text { concrete piles etc. }\end{array}$ & - $\quad$ The same as in the EN 15804. \\
\hline PCR for asphalt [29] & Asphalt pavements & $\begin{array}{l}\text { - EPD for A1-A5: a paved surface of } 1 \mathrm{~m}^{2} \text {, which } \\
\text { fulfils the specified quality criteria during the } \\
\text { Reference Service Life (RSL asphalt). }\end{array}$ \\
\hline & & $\begin{array}{l}\text { EPD for A1-A5 and as minimum B1 and B4: a } \\
\text { paved surface of } 1 \mathrm{~m}^{2} \text {, which fulfils the specified } \\
\text { quality criteria during the Reference Service Life of } \\
\text { the construction, in the case of roads a default value } \\
\text { of } 40 \text { years shall be take and for other constructions } \\
\text { types a value of } 30 \text { years. }\end{array}$ \\
\hline & & $\begin{array}{l}\text { EPD for A1-A3: } 1 \text { metric tonne of manufactured } \\
\text { asphalt mixture. }\end{array}$ \\
\hline & & $\begin{array}{l}\text { EPD for A1-A4: } 1 \text { metric tonne of manufactured } \\
\text { asphalt mixture delivered to the construction site. }\end{array}$ \\
\hline \multicolumn{3}{|c|}{ Road level } \\
\hline \multicolumn{3}{|c|}{ According to the "old" standard } \\
\hline $\begin{array}{l}\text { PCR for bridges, } \\
\text { elevated highways and } \\
\text { tunnels [30] }\end{array}$ & $\begin{array}{l}\text { Roads, elevated } \\
\text { highways as viaducts, } \\
\text { bridges, rock and } \\
\text { concrete tunnels }\end{array}$ & - $\quad 1 \mathrm{~km}$ of infrastructure and year. \\
\hline \multicolumn{3}{|c|}{ According to the new generation of standards } \\
\hline $\begin{array}{l}\text { EN } 15643-5: 2017[25] \\
\text { and prEN } 17472[26]\end{array}$ & $\begin{array}{l}\text { This framework standard } \\
\text { applies to all types of } \\
\text { civil engineering works, } \\
\text { both new and existing } \\
\text { (dam, bridge, road, } \\
\text { railway, runway, utilities, } \\
\text { etc.) }\end{array}$ & $\begin{array}{l}\text { - Comparisons between roads or parts of roads will } \\
\text { only be possible when the roads have the same } \\
\text { function (functional equivalence), the same system } \\
\text { boundary and equal scenarios. } \\
\text { - No specific reference unit is indicated in the } \\
\text { Standards. }\end{array}$ \\
\hline
\end{tabular}

The European standard, EN 15804, specifies an industry-approved method for the development of an EPD for a construction product. In the US, the EN 15804 with some modifications has been adopted as the international standard, ISO 21930. Both EN 15804 and ISO 21930 lay the foundation for all Product Categories Rules (PCR) and EPDs for building products and establishes principles regarding system boundaries, reported environmental impact categories, etc. The PCR for construction products and services [27] is based on EN 15804 [20] and used in various LCAstudies and EPDs [31, 32, 33]. The PCR for bridges, elevated highways and tunnels [30] is based on EN 15804 and establishes the functional unit to present the environmental impact as $1 \mathrm{~km}$ of a road and year. Some previous EPDs used this functional unit [34].

The EPD development process is usually accompanied by a program operator that defines and supervises the EPD process [35]. The Swedish-based operator, the EPD International [36], has published 525 EPDs for building materials, building products or components and 11 EPDs for buildings and engineering works. The Norwegian operator, EPD Norway, has published 437 EPDs for construction products [37]. Scandinavian manufacturers are free to select the program operator for publishing their EPDs. 
The EN 15643-5 and EN 17472 propose a new standardized framework which eventually will be used to create a new PCR for roads in the nearest future.

\subsection{Proposal on functional units for concrete pavements}

This study has implemented some main principles in EN 15643-5 and EN 17472 on some most used applications of the concrete road pavements, [3, 4, 38, 39, 40]. This study, based on the standardized framework in the analysed standards, proposes new functional units for the declaration of the assessment results for these applications, see Table 4.

The EN 15643-5 and prEN 17472 standards admit that the functional unit for presentation of the assessment results may differ for different road projects depending on their specific technical and functional requirements. The reason for that is that $1 \mathrm{~km}$ of a road may not be the fairest unit to compare alternative materials and road structure designs for different projects. According to the previous research at the Division of Concrete Structures at KTH [3 \& 4], the concrete pavement is a more cost-effective alternative than the asphalt pavements only in large-scale road projects. This is because of the need for more heavy technical equipment in the building of concrete roads. The challenges with the use of the concrete pavements stated in $\S 1.3$ contribute to a bias selection of the asphalt pavements in Swedish infrastructure projects.

The new approach proposed in these standards creates a bridge between the traditional technical design and optimization process and the environmental optimization. It is essential to identify the main set of functional parameters before performing any optimization process. The similar implementation of this new approach has been done in the Norwegian standard NS 3720:2018 [41] that illustrates how these new principles for assessment of more complex building systems can be apply to the climate impact assessment of a building. In the Norwegian standard, the number of visitors and other users of a designed building used as the main functional requirement. All this with the aim of maximizing the use of the designed building during its lifetime. In this way the use of all natural resources to build, to maintain and to use a building will be optimized. The "old" functional unit used for the buildings was the environmental impact per $1 \mathrm{~m}^{2}$ of building area [42] and used in the EPD for Folkhem's concept building [43]. 
Nordic Concrete Research - Publ. No. NCR 62 - ISSUE 1 / 2020 - Article 2, pp. 21-39

Table 4 - Proposed functional equivalences for various applications for concrete pavements and proposed new functional units.

\begin{tabular}{|c|c|c|c|c|}
\hline $\begin{array}{l}\text { Application } \\
\text { areas }\end{array}$ & Examples & Reason for selecting concrete & Level & $\begin{array}{l}\text { Proposed } \\
\text { functional } \\
\text { unit }^{*}\end{array}$ \\
\hline \multicolumn{5}{|l|}{ Only concrete } \\
\hline $\begin{array}{l}\text { Roads close } \\
\text { to urban } \\
\text { areas }\end{array}$ & $\begin{array}{l}\text { Use concrete } \\
\text { in high traffic } \\
\text { volume areas } \\
{[38]}\end{array}$ & - High traffic volume & $\begin{array}{l}\text { City } \\
\text { planning, } \\
\text { road network } \\
\text { level }\end{array}$ & $10 \mathrm{~km}^{* *}$ \\
\hline $\begin{array}{l}\text { Roads inside } \\
\text { tunnels }\end{array}$ & $\begin{array}{l}\text { Silfwerbrand } \\
{[3 \& 4]}\end{array}$ & $\begin{array}{ll}\text { - } & \text { Illumination } \\
\text { - } & \text { Reduced stresses } \\
\text { - } & \text { Fire safety } \\
\text { - } & \text { Long service-life with mi }\end{array}$ & Project level & $10 \mathrm{~km}^{* *}$ \\
\hline
\end{tabular}

Concrete \& asphalt pavements side by side

\begin{tabular}{|c|c|c|c|c|}
\hline $\begin{array}{l}\text { Asphalt } \\
\text { streets with } \\
\text { concrete bus } \\
\text { stops [40] }\end{array}$ & $\begin{array}{l}\text { Linköping } \\
(\mathrm{SE}), 40 \mathrm{~m}^{2}, \mathrm{~h} \\
=200 \mathrm{~mm}\end{array}$ & - $\quad$ Static, concentrated loads & Project level & $\begin{array}{l}\text { One bus } \\
\text { stop }\end{array}$ \\
\hline $\begin{array}{l}\text { Concrete } \\
\text { pavement } \\
\text { with asphalt } \\
\text { shoulder }\end{array}$ & & $\begin{array}{l}\text { - High traffic volume on pavement, low } \\
\text { volume on shoulder }\end{array}$ & $\begin{array}{l}\text { Road network } \\
\text { level }\end{array}$ & $10 \mathrm{~km}^{* *}$ \\
\hline $\begin{array}{l}\text { The } \\
\text { highway } \\
{[39]}\end{array}$ & $\begin{array}{l}\text { Concrete in } \\
\text { low speed lane } \\
\text { (K1) and } \\
\text { asphalt in high } \\
\text { speed lane } \\
\text { (K2) }\end{array}$ & - High traffic volume K1, low volume on K2 & $\begin{array}{l}\text { Road network } \\
\text { level }\end{array}$ & $10 \mathrm{~km}^{* *}$ \\
\hline \multicolumn{5}{|c|}{ Combination of asphalt and concrete } \\
\hline $\begin{array}{l}\text { Asphalt on } \\
\text { concrete }\end{array}$ & $\begin{array}{l}\text { Asphalt wear } \\
\text { layer on } \\
\text { cement-treated } \\
\text { base }\end{array}$ & $\begin{array}{l}\text { - } \quad \text { Enhanced load-carrying capacity } \\
\text { Intended to combine strength \& stiffness of } \\
\text { concrete with evenness \& riding comfort of } \\
\text { asphalt. } \\
\text { - The Swedish experience is not satisfactory: } \\
\text { Problems with reflection cracking are } \\
\text { frequent. }\end{array}$ & Project level & $10 \mathrm{~km}^{* *}$ \\
\hline $\begin{array}{l}\text { Concrete on } \\
\text { asphalt }\end{array}$ & Whitetopping & $\begin{array}{l}\text { Concrete top layer contributes to resistance } \\
\text { against concentrated \& sustained loads, } \\
\text { extreme temperatures (low, high, fire), and } \\
\text { wear while providing brightness. } \\
\text { Asphalt base layer contributes to flexural } \\
\text { strength \& ductility while reducing } \\
\text { construction costs. } \\
\text { Whitetoppings should not be used to repair } \\
\text { asphalt roads with improper load-carrying } \\
\text { capacity. } \\
\text { - Good bond between concrete \& asphalt } \\
\text { mandatory for composite action. } \\
\text { Enhanced wear resistance }\end{array}$ & Project level & $2 \mathrm{~km}^{* * *}$ \\
\hline
\end{tabular}

* Proposed in this study;

** $\quad$ Because of the large establishment cost for the production of a concrete road [3 \& 4];

*** Because of an easier and shorter production process for the whitetoping than for the other concrete applications [3 \& 4]. 


\section{4.}

\section{CONCLUDING REMARKS}

This paper identifies current needs and challenges for implementation of the new standardized framework for sustainability assessment of road pavement projects in Sweden and presents outlines of a newly started research project at the Division of Concrete Structures at KTH Royal Institute of Technology and the Nordic Construction Company (NCC).

Current road design and construction practices are specified by national guidelines that define the functional and technical performance and optimization criteria for a road as the whole structural engineering system. The environmental optimization is only performed on the material level. To make the LCAs and LCCAs an effective measure for reducing the environmental impact they have to be integrated with pavement design.

The application of sustainability assessment at the road level has previously been done for a few road projects, but not according to the EN 15643-5 or prEN 17472 reviewed in this study. The most used standard for the road projects is EN 15804 which describes the environmental assessment at the material level. The STA guidance on the climate assessment of infrastructure projects refers to the EN 15804 that defines calculation rules for the EPD for building materials. The guidance does not refer to the EN 15643-5 in any matter, although this standard is especially developed for the sustainability assessment of more complex engineering systems as roads are.

The prEN 17472 recommends conducting the LCA and LCCA with the same functional equivalence that are determined by the technical design guidelines at the road level, not at the material level. In this article, it was analyzed how technical and functional requirements for some common applications for concrete pavements can be used to form their functional equivalences according to the latest standards. The proposed functional equivalences for these applications are based on previous studies, national technical requirements and guidelines and can be used in the client's brief to set up requirements about LCA and LCCA in the road projects.

The main conclusion is that the current functional equivalent of $1 \mathrm{~km}$ a road may not be the fairest unit to compare the environmental impacts of alternative materials and road structural designs for different projects. The concrete pavement is more cost-effective alternative than the asphalt pavements only in large-scale and highly trafficked road projects. This is because of the need for more heavy and expensive technical equipment in the construction of concrete roads. This paper proposes a functional equivalence of a $10 \mathrm{~km}$ road that may solve that challenge.

\section{ACKNOWLEDGEMENTS}

The Swedish Construction Industry Development Fund (SBUF) is acknowledged for funding the project "Adaptation of road design to LCC and LCCA" (project ID: 13722).

\section{REFERENCES}

1. Swedish Transport Administration: "Climate requirements in planning, construction, maintenance phase and on technically approved railway equipment”, 2015:0480, version 3, Borlänge, Sweden, 2019. (In Swedish). 
2. Stockholm city, Malmö city, Göteborg city and Swedish Transport Administration: "Common environmental requirements for contractors". Stockholm, Malmö, Götrborg \& Borlänge, Sweden, 2018. In Swedish).

3. Silfwerbrand J: "The advantages of concrete pavements in tunnels". Proceedings, $12^{\text {th }}$ International Symposium on Concrete Roads, Prague, Sept. 24-26, 2014.

4. Silfwerbrand J: "Not concrete or asphalt but concrete and asphalt - A discussion based on Swedish pavements". Proceedings, $11^{\text {th }}$ International Conference on Concrete Pavements, San Antonio, Texas, USA, August 28-31, 2016, pp. 609-619.

5. Dolk E. "Concrete Pavements have a future" (in Swedish), Betong, No. 4, June 2017, pp. 4344. (In Swedish).

6. Strömberg L, Löfsjögård M, Ansell A \& Hintze S. "Optimization parameters sets for sustainable concrete in tunnels". Proceedings, $10^{\text {th }}$ Interdependence between Structural Engineering and Construction Management Conference, Chapter 19.6, ISBN: 978-09960437-6-2, doi: 10.14455/ISEC.res.2019.122, 2019.

7. EU directive 2014/24/EU on public procurement, February 2014.

8. The Swedish Parliament: "Act on Public Procurement 2016:1145", Stockholm, Sweden, 2016. (In Swedish).

9. Strömberg L: "Conceptual framework for calculation of climate performance with preverified LCA-Tools"- Journal of Civil Engineering and Architecture, Vol. 11, 2017, pp. 2937, DOI:10.17265/1934-7359.

10. Strömberg L, Khazanovichc L \& Hintze : "Enhancement of sustainable road design towards compatibility between pavement materials". Accepted for Proceedings of the $12^{\text {th }}$ International Conference on Concrete Pavements, Minneapolis, Minnesota, USA, 30 August - 3 September 2020.

11. Swedish Transport Administration: "Technical requirements for road construction". Borlänge, Sweden, 2011. TRV 2011:072, TDOK 2011:264, 2011. (In Swedish).

12. Swedish Transport Administration: "PMS Objekt". Borlänge, Sweden. available at: https://www.trafikverket.se/PMS-Objekt/, 2019.

13. Swedish Transport Administration: "User manual PMSV3- Information about roads". Borlänge, Sweden, 2018.

14. Swedish Transport Administration: "Support with LCC for planning and design of roads and railways". Version 1.1. Borlänge, Sweden, 2017. (In Swedish).

15. Lundberg R: "Energy efficient asphalt pavements: LCA tool EKA". Report, Swedish Transport Administration, Borlänge, Sweden, 2015. (In Swedish).

16. McKinsey \& Company: "Pathways to a low-carbon economy, Version 2 of the Global Greenhouse Gas Abatement Cost Curve". 2009, 192 pp.

17. McKinsey \& Company: "Impact of the financial crisis on carbon economics. Version 2.1 of the Greenhouse Gas Abatement Cost Curve". 2010, 14 pp..

18. International Energy Agency: "Summing up the parts. Combining policy instruments for least-cost climate mitigation strategies". 2011, 72 pp.

19. Swei O, Reed Miller T, Akbarianc M, Gregory J, Kirchaine R: "Effects of industry competition in the paving sector". Manuscript under review in the journal Transport Policy, 2019.

20. EN 15804:2012+A1:2013: "Sustainability of construction works -Environmental product declarations - Core rules for the product category of construction products". 2013.

21. ISO 21930:2017: "Sustainability in buildings and civil engineering works - Core rules for environmental product declarations of construction products and services". 2017.

22. Strömberg L, Wendel M, Berglund M \& Lindgren Å: "Digitalization of EPDs for asphalt experience from Sweden and input from Norway\#. Accepted for Proceedings of $7^{\text {th }}$ Eurasphalt \& Eurobitume Congress, Madrid, 12-14 May 2020. 
23. Strömberg L: "Current difficulties with creation of standardized digital climate calculations for infrastructural projects". Proceedings, Pavement Life-Cycle Assessment Symposium, Champaign, Illinois, USA, April 12-13, 2017, pp. 23-29, ISBN: 978-1-315-15932-4 (eBook).

24. www.sis.se/standardutveckling/tksidor/tk200299/sistk202/ Retrieved on August 2019.

25. EN 15643-5:2017; "Sustainability of construction works - Sustainability assessment of buildings and civil engineering works - Part 5: Framework on specific principles and requirement for civil engineering works". 2017.

26. prEN 17472. "Sustainability of construction works - Sustainability assessment civil engineering works - Calculation methods". February 2020.

27. PCR, Product Category Rules for Construction Products and Construction Services 2012:01, version 2.2. Owner: EPD International, 2012.

28. Sub-PCR to PCR 2012:01 Concrete and concrete elements (EN 16757:2017), PCR 2012:01SUB-PCR-G, Owner: EPD International, 2018.

29. PCR, Product Categories Rules Asphalt Mixtures Product category classification: UN CPC 1533 \& 3794, 2017:01 Version 1.0. Owner: EPD International, 2018.

30. PCR, Product Category Rules for bridges, elevated highways and tunnels, Version 1.11. Owner: EPD International, 2019.

31. Environmental Product Declaration for NCC Green Asphalt ${ }^{2}$ from Arlanda asphalt plant, Owner: NCC, Program operator: EPD International, Reg. no. S-P-00844, Date 2017-01-30. Valid until 2022-01-26.

32. Environmental Product Declaration for asphalt mixtures from Uddevalla asphalt plant Porsen, Owner: NCC, Program operator: EPD International, Reg. no. S-P-01641, Date: 201912-19, Valid until 2024-12-18.

33. Environmental Product Declaration Grön betong, Owner: Skanska Industrial Solutions AB, Program operator: EPD Norge, Reg. nr. NEPD-1717-700-SE, Date 2019-03-11, Valid until 2024-03-11.

34. Environmental Product Declaration for the Railway Infrastructure on the Bothnia Line, Owner: Swedish Transport Administration, Program operator: EPD International, Reg. no. S-P-00196, Date 2016.

35. Bovea M D, Ibáñez-Forés V \& Agustí-Juan I. "Environmental product declaration (EPD) labelling of construction and building materials". In: Eco-efficient Construction \& Building Materials, 2014, pp. 125-150. Sawston, UK.

36. EPD International, 2019. www.environdec.com. Retrieved on August 2019.

37. EPD Norway, 2019. www.epd.no. Retrieved on August 2019.

38. Cormier B \& Thébeau D: "Determination of a dedicated concrete pavement network using probabilistic Life-Cycle Cost Analysis". Proceedings, $9^{\text {th }}$ International Symposium on Concrete Roads, Istanbul, Turkey, April 3-7, 2004, 11 pp..

39. Hultqvist B-Å \& Dolk E, "Betongbeläggning i tungt trafikerade körfält på motorväg. Exempel och erfarenheter från några olika länder". (“Concrete pavements in heavily trafficked lanes on motorways. Examples and experiences from some different countries".) VTI Report No. 837, Swedish National Road and Transport Research Institute, Linköping, Sweden,2015, 44 pp. (In Swedish).

40. Svensk Byggtänst: "Betong på mark - Platsgjutna lösningar”. ("Concrete Slabs on Ground Cast-in Place Solutions”.) Handbook, Stockholm, Sweden, 2002. (In Swedish).

41. NS 3720:2018 Methods for greenhouse gas calculations for buildings. Published 2019-0418.

42. PCR, Product Categories Rules 2014:02 Buildings. Version 2.01. Program operator: EPD International. 
Nordic Concrete Research - Publ. No. NCR 62 - ISSUE 1 / 2020 - Article 2, pp. 21-39

43. Environmental Product Declaration for Folkhem's concept building, Owner: Folkhem, Program operator: EPD International, Reg. nr. S-P-00652, Date 2015-09-29, Valid until 2018-09-29. 